\title{
Keynote Address by Abdulqawi A. Yusuf
}

\author{
President of the International Court ofJustice
}

I am honoured to have been invited here to deliver the keynote address, and I am particularly happy that my first speech before you as President of the International Court of Justice should be on the occasion of the seventieth anniversary of the International Law Commission.

As a judge of the International Court, but also first and foremost as an international lawyer, the work of the International Law Commission has played, and continues to play, a crucial role in my daily work. Your dedication - and that of your predecessors - has allowed the international legal system to develop into what it is today. For that, on behalf of international lawyers everywhere, I thank you. Of course, in the first rank of these international lawyers are my colleagues at the International Court of Justice, many of whom have passed through the Commission and have asked me to convey to you their congratulations on this 7oth anniversary as well as their best wishes for the future.

The theme of today's celebration is "Drawing a Balance for the Future", but I want to take a few minutes to look back into the past in order to understand the role that the International Law Commission has played over the past seven decades. This brings to mind an African proverb, which says: "If you want to know the end, look at the beginning."

The twentieth century was a time of particular upheaval for the international legal system. On the one hand, the century marked the evolution of the international law from a system that was applicable only among a small circle of European States to one that has a credible claim to be a universal legal system, one in which States from all corners of the globe participate. On the other hand, international law moved away from a Westphalian, State-centric system towards a legal order that recognizes and responds to the needs of a plurality of actors, including international organizations, individuals, and corporations. These are only two of the many challenges that the International Law Commission has had to deal with from its inception in 1947.

Resolution 174 (II) of the United Nations General Assembly entrusted to the Commission the task of "the promotion of the progressive development of international law and its codification". 
The question that I want to address is the following: how did the International Law Commission fulfil its mandate in light of these challenges, and in particular in respect of the changes to the structure and composition of the international community that have occurred over the past 70 years? How did the Commission contribute to the adaptation of international legal rules to the profound societal changes on the international plane?

To respond to this question, we need to look back to the predecessor of the International Law Commission, the Committee of Experts for the Progressive Codification of International Law of the League of Nations, which was created in 1924. That Committee, although purportedly composed of "the main forms of civilization [...] of the world", manifested the deeply Eurocentric character of the international law of the early twentieth century, both in terms of its membership and its mission.

With regard to the composition of the Committee, although it included jurists from China and Japan, most of the Afro-Asian members of the League, such as Siam, Ethiopia, Liberia and Egypt, were not represented on the Committee. In relation to the mandate of the Committee, the codification of international law was, at that time, understood in a narrow sense of the term. The intention was the codification or systemization of the usages and practices of a self-styled club of "civilized States" that arrogated to itself the right to exclude or admit other nations into the scope of application of international legal rules.

The debate in the League of Nations on the Italian invasion of Ethiopia testifies to the continued prevalence of this 19th century conception of international law until the 1930 .

However, by the time the International Law Commission was established in 1947, the world was undergoing dramatic changes. The Atlantic Charter and the Charter of the United Nations, which were adopted in 1941 and 1945, respectively, laid the foundation for a new international law with universalist aspirations organized around the principle of equal rights and self-determination of peoples and on a universal protection of human rights. These emerging norms were enriched by the views and positions articulated by the newlyindependent States, and in particular by two instruments through which they proclaimed those views.

The first was the Bandung resolution that was adopted by the Asian-African Conference in 1955, which declared that "colonialism in all its manifestations is an evil which should speedily be brought to an end". That resolution also demanded the admission to the United Nations of Cambodia, Ceylon, Japan, Jordan, Nepal, and Vietnam, laying the groundwork for the influential NonAligned Movement. 
The second milestone was the adoption by the General Assembly of resolution 1514 (xv) of 14 December 196o, entitled the "Declaration of the Granting of Independence to Colonial Countries and Peoples". That resolution recalled "the necessity of bringing to a speedy and unconditional end colonialism in all its forms and manifestations" and proclaimed that "the subjection of peoples to alien subjugation, domination and exploitation constitutes a denial of fundamental human rights, is contrary to the Charter of the United Nations and is an impediment to the promotion of world peace and cooperation."

These declarations marked the beginning not only of a wide-spread process of decolonisation in Asia and Africa in the decades that followed and the resultant changes in the composition of the international community, but also the emergence of new perspectives of and attitudes to international law.

\section{The Response of the International Law Commission}

As Wolfgang Friedmann stated in his famous book The Changing Structure of International Law:

The main significance of this horizontal extension of the members of the family of nations does not, however, lie in the explosive increase of the numbers. It lies in the increasing dilution of the homogeneity of values and standards derived from the common Western European background of the original members. ${ }^{1}$

At the time of the creation of the Commission there were only 57 Member States of the United Nations; there are now 193. This change is not merely numerical; it represents a profound societal change involving the emergence of a diverse body of actors, each with their own culture, customs and legal traditions. These changes strengthened the mission of the International Law Commission and laid the foundations for its ability to contribute to the formation of a universal international legal order.

Similarly, it was not so much the increase in the membership of the International Law Commission, which was enlarged from 15 to 21 in 1956, then to 25 in 1961 , and finally to its current 34 members in 1981, but its ability to account in its work for the diversity of perspectives of international law, which was born

1 Wolfgang Friedmann, The Changing Structure of International Law (Columbia University Press 1964) 5-6. 
as a result of decolonization, that has smoothed the way for its achievements in the last 70 years. This was in turn rendered possible by the provision, in article 8 of the statute of the International Law Commission, that members of the Commission shall represent "the main forms of civilization and ... the principal legal systems of the world", ${ }^{2}$ an article that reflects the wording of article 9 of the Statute of the International Court of Justice. That article reproduces the corresponding provision of the Statute of the Permanent Court of International Justice, which has become much more important today than the drafters of the Statute of the Permanent Court of International Justice could have ever imagined. The same may be said of article 8 of the Statute of the International Law Commission.

As I mentioned before, the rules of customary international law that existed at the time the Commission was created were derived from the practice of European States. But against the backdrop of decolonisation, the International Law Commission realized that codifying these rules, in the sense of their systemization, no longer reflected international reality. It therefore decided two things: first, that it was necessary to take into account the views and perspectives of the new States and their legal systems. Secondly, in order to do that, the Commission decided to consider as one the two limbs of its mandate, codification and progressive development. As you put it, Mr. Chair, the Commission merged the two limbs. One of the reasons why this was done was to avoid that the Commission's work be limited to a systemization of practices and rules, some of which were out of tune with the new realities of the international community.

The challenges faced by the Commission were described by the Dutch jurist, Bert Röling, who, in his 1960 book International Law in an Expanded World, concluded that:

A new international law, consonant with the new sociological structure of the community of nations, and consonant with the new legal conceptions expressed in it, must be evolved. Such an evolution is [a] prerequisite for the existence of "one world" which should be both a welfare community and a community of peace.

Let me explain why I think this is so important. I would mention two reasons. The first is the need for diversity in the international legal sphere. It is not a

2 UNGA Res 174 (II) (21 November 1947), as amended by UNGA Res 485 (V) (12 December 1950), Unga Res 984 (x) (3 December 1955), Ung Res 985 (x) (3 December 1955) and Unga Res $36 /$ 39 (18 November 1981). 
paradox to say that the universality of international law depends on diversity. For international law, universalization means borrowing and adapting concepts and principles from different legal traditions. The more international law can draw on multiple legal traditions, the more universal it will be considered.

The second reason is legitimacy. The legitimacy of international law depends, to a great extent, on its ability to reflect the perspectives of all components of the international community. As observed by Georges Abi-Saab:

[I]f we really want international law to take hold and be taken seriously by all, it has to be, and be seen to be, both in its creation and in its interpretation and application, the product of this community as a whole, reflecting, by synthesis or symbiosis, the legal visions, needs and aspirations of all the components of this community. ${ }^{3}$

The work of the International Law Commission demonstrates a willingness to reflect the international community in all its multifaceted splendour. The International Law Commission demonstrated this early on not only through its work but also through the recognition of the importance of the individual contributions of rapporteurs from Afro-Asian countries, starting in the 196os with Abdullah El-Erian, and followed by Mohammed Bedjaoui, Sompong Sucharitkul, and Doudou Thiam, to name but a few.

Although the work of these individuals was important, the work of the Commission as a whole demonstrates an openness to diverse perspectives, which have left an indelible mark on the contours of contemporary international law. Due to the constraints of time, let me mention just two examples of the concrete manner in which the Commission took into account the viewpoints of the newly-independent States in its early work on codification and progressive development already in the 196os and 1970s, in an area which was profoundly marked by the practices and usages of the old club of the "concert européen", i.e. the law of treaties.

\section{i The Termination of Treaties}

I will start with the inclusion in the Commission's work on the law of treaties of provisions related to the termination of treaties. Newly independent States spoke out against the imposition of treaties thrust upon them by force or fear,

3 Georges Abi-Saab, 'The Portrait of the Jurist as an International Judge' in Connie Peck and Roy Lee (eds), Increasing the Effectiveness of the International Court of Justice: Proceedings of the ICJ/UNITAR Colloquium to Celebrate the 5oth Anniversary of the Court (Martinus Nijhoff Publishers 1997) 166, 171. 
as well as treaties of capitulation. During debates on the International Law Commission's 1966 draft articles on the law of treaties, delegates to the Sixth Committee of the General Assembly expressed the view that:

[T] he draft articles on the law of treaties could not acknowledge unjust, unfair or unequal treaties, which in many cases were the consequence of the colonial system. Instruments imposed without the consent of the populations concerned, instruments which were the price of accession to independence, instruments taking advantage of the situation of the developing countries ... could not be protected by the law of treaties, and should be eliminated from international relations. ${ }^{4}$

The work of the International Law Commission took into account these concerns by including, in particular, what would become article $5^{2}$ of the Vienna Convention on the Law of Treaties, providing that "[a] treaty is void if its conclusion has been procured by the threat or use of force ...." ${ }^{5}$

\section{ii Succession of States to Treaties}

A second example is the work of the Commission on the succession of States in respect of treaties. At the time of independence, a number of African States adhered to what later came to be known as the Nyerere doctrine of State succession. According to this doctrine, newly independent States would provisionally apply bilateral treaties on a reciprocal basis for a two-year period from the date of independence, to the extent that those treaties were compatible with the sovereign rights of the new States. This two-year period was considered as a time of reflection by a decolonized State on whether it decided to be bound by the treaty, to renegotiate it, or to abandon the treaty altogether.

During this period, the International Law Commission was also conducting its work on the "Succession of States and Governments", in relation to which the General Assembly urged the Commission to undertake its work "with appropriate reference to the views of States which have achieved independence since the Second World War", including - importantly - the principle of selfdetermination. ${ }^{6}$

This led the Commission to state that:

4 Felix Okoye, International Law and the New African States (Sweet and Maxwell 1972), 191.

5 Vienna Convention on the Law of Treaties, adopted in Vienna on 23 May 1969, entered into force 27 January 1980, 1155 UNTS 331.

6 UNGa Res 1902 (XVIII) (18 November 1963). 
The traditional principle that a new State begins its treaty relations with a clean slate, if properly understood and limited, was in the opinion of the Commission more consistent with the principle of self-determination. ${ }^{7}$

The Nyerere doctrine was thus fully reflected in the International Law Commission's draft articles, which served as the basis for the Vienna Convention on Succession of States in respect of Treaties. ${ }^{8}$ In particular, article 16 of that Convention provides that:

A newly independent State is not bound to maintain in force, or to become a party to, any treaty by reason only of the fact that at the date of the succession of States the treaty was in force in respect of the territory to which the succession of States relates.

\section{iii The Future of the International Law Commission's Work}

These two examples illustrate, in my view, how the International Law Commission has successfully taken into account views of diverse actors in order to develop progressively and codify an international law with universal aspirations. That is an exceptional achievement.

Let me briefly mention two other notable examples. First, the inclusion of the concept of peremptory norms (or jus cogens) in the International Law Commission's work on the law of treaties, and its subsequent inclusion as articles 53 and 64 of the Vienna Convention on the Law of Treaties, has had a lasting impact on the structure of international law. As eloquently put by Mustafa Yasseen, the Chair of the Drafting Committee of the Vienna Conference, jus cogens are "those higher norms which [are] essential to the life of the international community and [are] deeply rooted in the conscience of mankind". $9 \mathrm{Al}-$ though initially controversial, the concept now commands widespread acceptance among States and other international actors. This is in large part thanks to the efforts of the Commission, and its on-going work on jus cogens attests to the enduring importance of the topic.

Second, the Commission's work on the succession of States in respect of matters other than treaties, is particularly notable insofar as it acknowledged

7 ILC, 'Report of the International Law Commission on the work of its twenty-fourth session' [1972] II ILC Ybk 227.

8 Vienna Convention on Succession of States in respect of Treaties, adopted in Vienna on 23 August 1978, entered into force 6 November 1996, 1946 UnTs 3.

9 United Nations Conference on the Law of Treaties, First Session, Vienna, 26 March-24 May 1968, Official Records, A/CONF.39/11, 295 and 296. 
explicitly the principle of permanent sovereignty over natural resources, a principle which was strongly promoted and defended by the newly-independent States. This led to the inclusion of the principle in article 15, paragraph 4, of the Vienna Convention on Succession of States in respect of State Property, Archives and Debts. ${ }^{10}$

Through its work, the Commission has clearly shown the adaptability of legal rules to societal change. The scope and number of international legal rules recognized by all members of the international community has increased through the Commission's efforts, and it has succeeded to shift the principal source of law-making from custom to multilateral conventions and a codified set of rules in which, as the Court said in its advisory opinion on the Genocide Convention, "the contracting States ... have, one and all, a common interest ...".11

At the start of my address, I noted that two changes over the course of the twentieth century were particularly important for international law: first, the decolonization process and the resulting changes in the structure and composition of the international community; and, second, the movement away from a Westphalian, State-centric system of international law to one that recognizes a plurality of actors.

As I have mentioned above, the Commission has responded convincingly to the first of these changes. In relation to the second, however, as my colleague (and former member of the Commission), Giorgio Gaja, has noted, ${ }^{12}$ there is still some work to be done. Let me mention just one example.

Whilst certain elements of the International Law Commission's work recognize the ability of individuals to hold rights under international law, such as article 33, paragraph 2, of the articles on State responsibility, the Commission has only acknowledged as recommended practice, under the articles on diplomatic protection, the important fact that reparations should accrue to an aggrieved individual in cases where their rights are breached.

The Court has not done much better. In the Diallo Judgment on Compensation, it simply recalled that "the sum awarded to Guinea in the exercise of diplomatic protection of Mr. Diallo is intended to provide reparation for the latter's injury". ${ }^{13}$ In my view, both the International Law Commission and the

10 Vienna Convention on Succession of States in respect of State Property, Archives and Debts (adopted in Vienna on 8 April 1983, not entered into force yet), (1983) 22 ILM 306.

11 Reservations to the Convention on the Prevention and Punishment of the Crime of Genocide (Advisory Opinion) [1951] ICJ Rep 15, 23.

12 Giorgio Gaja, 'The Position of Individuals in International Law: An ILC Perspective' (2010) 21 EJIL 11, 12.

13 Ahmadou Sadio Diallo (Republic of Guinea $v$ Democratic Republic of the Congo) (Compensation) [2012] ICJ Rep 324, 344. 
Court should have asserted that reparations accrue to individuals in case of injury to their rights. To borrow the words of Giorgio Gaja, this would create a "comprehensive" and "coherent" approach to the place of individuals under international law.

But the future holds greater challenges for the Commission, and for the international legal system more generally. Recent developments show that the most fundamental rules and principles of international law are under threat. As the International Court of Justice stated in the Corfu Channel case, certain international obligations are based on "elementary considerations of humanity, even more exacting in peace than in war". ${ }^{14}$ These norms are being questioned today by those that want to promote unilateralism and turn their back on a world order based on multilateralism. We also see the sanctity of treaties and pacta sunt servanda increasingly under tension, as international treaty commitments are repudiated virtually before the ink has dried on the paper on which they were written. There are attempts to render agreements among States the world over less durable and more fragile, and to equate a change of government or of political parties in power to the doctrine of rebus sic stantibus.

The International Law Commission must play a role in responding to these threats. In particular, the Commission must promote multilateralism and inclusiveness, and create awareness among governments of the need and the importance of these concepts to the rule of law at the international level. In sum, the Commission has to continue to show the way for a better observance of the rules of international law in the interest of humanity as a whole.

Throughout the 70 years of its existence, the International Law Commission has played a pivotal role in ensuring that international law responds to the needs of all the members of the society it serves. It is now needed more than ever. It must spread the word that the well-being and progress of all nations depends on multilateral co-operation based on the rule of law - and that peace and harmony among nations requires shared values and common standards and rules based on those values. That is a difficult challenge, but one that I have no doubt that the Commission will live up to.

14 Corfu Channel case (United Kingdom v Albania) (Merits) [1949] ICJ Rep 4, 22. 